Open Access

\title{
Developing eLearning champions: a design thinking approach
}

\author{
Daniela Gachago*, Jolanda Morkel, Liza Hitge, Izak van Zyl and Eunice Ivala
}

\author{
* Correspondence: \\ gachagod@cput.ac.za \\ Cape Peninsula University of \\ Technology, PB652, Cape Town \\ 8000 , South Africa
}

\begin{abstract}
Against the backdrop of a complex Higher Education (HE) landscape, particularly in a developing country context where the relevance of current HE structures is questioned through student protests, and decolonisation of education practices is called for, traditional thinking is losing ground. This study focuses on lecturers identified as eLearning champions, who display shared dispositions that mirror what the literature terms a 'design thinking mindset', such as collaboration, empathy for the learner and problem orientation. We argue that promoting this mindset in academic staff development interventions around the use of technology in teaching and learning could support more academics to innovate their practices. Recommendations for how findings of this study may inform the design of such learning interventions conclude the paper.
\end{abstract}

Keywords: Design thinking, Design thinking mindset, eLearning champions, Academic staff development, South Africa

\section{Introduction}

With the increasing complexity of the Higher Education landscape, traditional thinking is losing ground. This is particularly true for developing countries, where decolonisation processes are in full swing and students question the higher education structures still rooted in colonial times. How can the needed change of structure be set in motion? While digital technology has revolutionised our life and work, uptake in Higher Education has been limited and slow in many cases (Adams Becker, Cummins, Davis, Freeman, Hall Giesinger, et al., 2017; Laurillard, 2012). South Africa is no exception (Ng'ambi, Brown, Bozalek, \& Gachago, \& Wood, D., 2016). The institutional adoption of innovation depends on many factors, external and internal, institutional, cultural and personal. Higher education institutions globally are described as conservative and resistant to change, and even more so in the Global South (Uys, Nleya, \& Molelu, 2004). The low uptake of digital technology for teaching in South African higher education is for example linked to poor infrastructure, top-down and deterministic institutional implementation, organisational cultures defined by low recognition of excellence in teaching and learning, lacking incentives for innovation in teaching and learning, poor institutional leadership, low digital literacy among students and staff, and prevailing social attitudes toward technology (Bozalek \& Ng'ambi, Gachago, 2013; Cloete \& Gillwald, 2014; Van Zyl, \& Sabiescu, A., 2016).

(c) The Author(s). 2017 Open Access This article is distributed under the terms of the Creative Commons Attribution 4.0 International License (http://creativecommons.org/licenses/by/4.0/), which permits unrestricted use, distribution, and reproduction in any medium, provided you give appropriate credit to the original author(s) and the source, provide a link to the Creative Commons license, and indicate if changes were made. 
While we see the necessity for concerted top-down and bottom-up processes for innovation adoption in higher education (Uys, 2007), this paper focuses on the infusion of innovation (Rogers, 2010) as lead by eLearning champions. This research is part of a larger project that evaluates current staff development initiatives aimed at supporting academics with the integration of technology into their teaching and learning at a large University of Technology in South Africa. As part of this project, we interviewed thirteen eLearning champions, i.e. academics who are known for innovative practice through the creative use of technology, across the six faculties of the institution. What became evident over the course of the interviews was that they shared similar behaviour, attributes and attitudes - what we would frame as a design thinking mindset.

Smulders, Dorst, and Vermaas (2014) suggest that design thinking, as a methodology for developing novel solutions to complex, real-world problems that originated in the design professions, is rapidly gaining ground in other fields like business, management and higher education innovation. Although there is little consensus about the definition of design thinking, there is general agreement that it is human-centred, fundamental to everyday human activity and deals with complex and ambiguous issues (Di Russo, 2016).

The first formal reference to design thinking was made by Peter Rowe in his 1987 book with the same title. In response to the initial scientific approach to design, Nigel Cross, Donald Schön, Bryan Lawson, Peter Rowe, Bruce Archer and Richard Buchanan advocated for a move away from a formulaic logic towards a cognitive approach, including 'tacit intuition unique to a designer' (Di Russo, 2016, p. 22), that is a 'designerly way of knowing' (Cross, 2007, p. 7).

Contemporary design thinking is described as both a method and a mindset, and owes much of its recent prominence in non-design domains to the Stanford Design School and the consultancy agency, IDEO (Di Russo, 2016). Although there are studies exploring ways to promote a design thinking mindset in educational settings to address 'wicked problems' in education (Luka, 2014; Koh, Chai, Wong, \& Hong, 2015; Rauth, Köppen, Jobst, \& Meinel, 2010; Ulibarri, Cravens, Cornelius, Royalty, \& Nabergoj, 2014), we have not encountered literature in the context of academic staff development (although this special issue is a means to address this gap). This paper has two aims: to first identify shared characteristics of recognised eLearning champions and second, to explore design principles for staff development programmes to promote these characteristics and determine whether such a design mindset can be developed as some of the literature suggests (Rauth et al., 2010).

\section{Design thinking mindsets}

This paper presents shared characteristics of a specific group of individuals, whom we call 'eLearning champions'. To define these academics, we use Beath's (1991, p. 355) seminal definition of technology champions. According to Beath, champions are "individuals who emerge to take creative ideas (which they may or may not have generated) and bring them to life. They make decisive contributions to the innovation process by actively and enthusiastically promoting the innovation, building support, overcoming resistance, and ensuring that the innovation is implemented".

These shared characteristics seem to fit a design thinking mindset (Rauth et al., 2010). When examining the literature, a number of design thinking characteristics overlap (Luka, 2014). Typical characteristics of a design thinking mindset or design 
dispositions are: being comfortable with open-ended situations without predetermined outcomes; being empathetic to the needs of the user and engaging in exploration (Michlewski, 2008); and managing uncertainty, taking calculated risks, learning from failures and relying on personal judgment rather than accepting existing solutions (Cross, 2011). Lawson's (2005) concept of open-mindedness, which means embracing inputs from multiple disciplines and sources, is relevant here, as well as Owen's (2007) characteristics of design thinking that include human- and environmental-centred concerns, the ability to visualise, predisposition toward multifunctionality, systemic vision, ability to use language as a tool and an affinity for teamwork (Owen cited in Razzouk \& Shute, 2012). Razzouk and Shute (2012) add the concepts of persistence and adaptation. Baeck and Gremett (2012) summarise design thinking characteristics into nine categories: ambiguity, collaboration, constructiveness, curiosity, empathy, holism, iteration, non-judgemental and openness. MacQuaid's (2015) list of characteristics consists of the following 16 elements: action-oriented, adventurous, clear-communicator, collaborative, curious, empathetic, flexible, humble, imaginative, iterative, meticulous, optimistic, passionate, process-oriented, systems-thinking and tangible.

For our study we found the d.mindsets by the Hasso Plattner Institute of Design at Stanford (d.school, 2011) and its focus on embedding design thinking more broadly in education useful. Their practice and empirical research focuses on the integration of design thinking in higher education across faculties, disciplines and continents (Rauth et al., 2010). The design thinking model they developed lists seven elements that are vital for a design thinker: a focus on human values, the ability to craft clarity, embracing experimentation, being mindful of the process, a bias towards action, radical collaboration and a preference to rather show than tell (see Fig. 1). What is of particular interest to us, is that their research shows that design thinking is not necessarily a natural talent, but a skill that can be learnt (Rauth et al., 2010; Lawson, 2005) through unconscious adoption as much as through formal training (Porcini, 2009). This argument will be addressed in the second half of the paper.

\section{Research methodology}

In this qualitative case study, we explore the characteristics and dispositions exhibited by innovative HE practitioners. The study is part of a larger mixed-methods research project, which evaluated the impact of academic staff development activities around the use of technology in teaching and learning through surveys and interviews (Ivala, 2016). Participants in the larger project were selected following purposive, nonprobability sampling techniques (all had participated in staff development activities and were known to the research team for either integrating technology in their practices or not). Interviews of 30-60 min were facilitated by two members of the research team. For this paper we analysed the interviews of one group only - a group we define as eLearning champions - academics known in their departments to use technology innovatively and who serve important functions of connecting central service units such as the Centre for Innovative Educational Technology with departments and faculties. It is important to clarify that these are not teaching and learning or technology experts, but academics, who have been using technology for a while and in innovative ways (Table 1). 


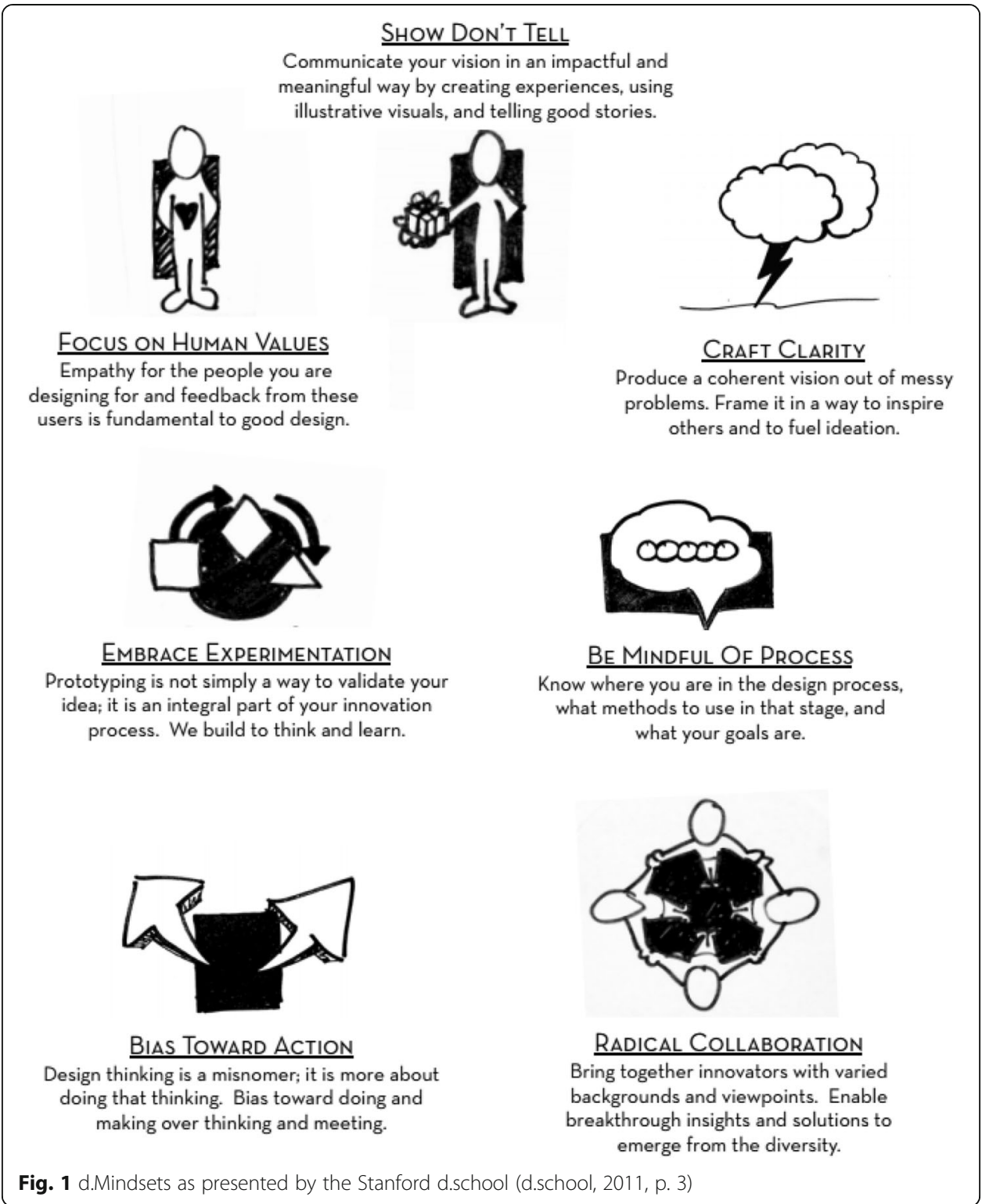

Interview questions were designed to elicit personal insights and perspectives on academic staff development, particularly on the impact of academic staff training activities, such as formal and informal training opportunities, consultations with staff developers and collaborative research projects on their teaching practices. Following this phase, interviews were transcribed and later analysed independently by two of the authors following an open, thematic coding protocol. Thematic analysis is an inductive, constructivist process and involves the search for and identification of common 'themes', threads or patterns that occur within a dataset (Vaismoradi, Turunen, \& Bondas, 2013). As a flexible method it can provide the interpreter with a rich and nuanced account of complex data (ibid).

The researchers followed six recursive and nonlinear phases of thematic analysis, as identified by Braun and Clarke (2006, pp. 16-24), namely: 
Table 1 Participants of this study (champions only)

\begin{tabular}{llll}
\hline Identifier & Faculty & Role & Sex \\
\hline FID & Informatics and Design & Senior lecturer & Female \\
AS & Applied Sciences & Lecturer & Female \\
EDU1 & Education & Lecturer & Female \\
EDU2 & Education & Senior lecturer & Female \\
EDU3 & Education & Senior lecturer & Female \\
ENG1 & Engineering & Lecturer & Male \\
ENG2 & Engineering & Lecturer & Male \\
ENG3 & Engineering & Lecturer & Female \\
BUS1 & Business & Lecturer & Male \\
BUS2 & Business & Lecturer & Female \\
HW1 & Health and Wellness & Lecturer & Female \\
HW2 & Health and Wellness & Librarian & Female \\
HW3 & Health and Wellness & Lecturer & Female \\
\hline
\end{tabular}

1. familiarisation (immersive reading and re-reading of the data)

2. coding (conceptual and semantic reading, probing and collation of the data)

3. thematic searching (identifying and constructing meaningful, coherent patterns)

4. reviewing (unpacking the relationship between themes; discerning a broader thread)

5. definition (constructing a detailed analysis of each theme)

6. writing (construction of coherent analytic narrative)

A first round of analysis revealed a strong presence of characteristics of design thinking among the champions group. These academics are not necessarily typical technology innovators - not all would be characterised for example as 'innovators' or 'early adopters' (Rogers, 2010). They differ widely in terms of age, digital literacy skills, confidence in using technology or technology training. However, there were cross-cutting themes, such as collaboration, reflection and learner empathy - all elements of a design thinking mindset. For purposes of triangulation and inter-coder reliability, a second round of analysis was then conducted in which we re-examined the codes through the lens of design thinking literature and concepts. This more detailed round involved two more colleagues, known for their expertise in design thinking. The second round analysis revealed that principles of design thinking directly or indirectly framed or informed the professional practice of these champions, and were consequently mapped on existing models of design thinking mindsets. Ethical clearance was sought through appropriate institutional channels. For purposes of confidentiality, participant accounts are anonymised.

\section{Findings}

From the analysis of the interview data, seven key themes emerged, which are described below. All seven themes were present across the interviews, however the strength of the theme decreases along the list. The two strongest themes were collaboration and generosity, and learner empathy. 
Theme 1: Collaboration and generosity

Design thinkers are strong collaborators. In their interviews, champions highlight the importance of teamwork and emphasise relationship-building through collaborative teaching, projects and research (comment 1). The champions support colleagues and share their knowledge in and beyond their departments. They further indicate that relying on a core group of interdisciplinary colleagues with a diverse skill set helps them to establish their influence in the department to infuse bottom-up innovation (see comment 2).

Comment 1: “... a lot of what has informed my practice has been through people's inputs and discussions and, you know, try this and that. So it's like little baby steps, trying things out and then reflecting on how it's working or not." (FID).

Comment 2: “... working with cooperative people in your department helps. ... we've even got some collaborative classes, where we take all three years. And we now have integrated studio classes where we try to encourage like peer to peer learning and we put little activities and classes together. And so it does really help when you've got other people who are on board and share the same vision to work together." (AS).

\section{Theme 2: Learner empathy}

A passion for learning and empathy for their learners, drive these champions. Lecturers are willing to listen to their learners and to their needs and find individualised solutions that suit their contexts. They look for what 'works for them', rather than abiding by institutional policy and guidelines (see comments 3 and 10). They are mindful of differently positioned students, challenge dominant notions such as the digital natives discourse (Brown \& Czerniewicz, 2010), and favour a more nuanced, context-sensitive approach to innovation (see comment 4).

Comment 3: "If Blackboard [institutional LMS] can work for certain things, fantastic and if Blackboard is down, I put my stuff on Dropbox. Do you know what I mean? So students can access it. I don't care about Blackboard. I care about my students." (BUS1).

Comment 4: “...when we did that Tablet Pilot Study, one of our questions was how comfortable do you feel with technology? And because students are all on their phones, they all picked like a 4 or a 5 . And once we started working with the tablets, in our interim survey we asked if they were comfortable with technology and it went down significantly by two points. People were now on two or three. So I think the students don't know what they don't know..." (AS).

\section{Theme 3: Problem orientation}

Instead of being discouraged by environments often experienced as 'hostile' to the use of technology in teaching and learning, these lecturers find ways to engage these challenges, often using their own resources to do so (see comments 5 and 6 but also 14). It appears as if these challenges motivate them to find creative answers in resource-poor contexts.

Comment 5: “... internet access on campus is a big problem. [...] I resort to downloading stuff at home where I've got a proper internet. Not everybody has that. Then I resort to using my cell phone hotspots in the lecture hall. That also doesn't always work because sometimes the cell phone signal is too poor and you can't use hotspots. But the best for me is to download beforehand because then you know that technology won't fail you..." (EDU1). 
Comment 6: "Some lecturers told me: but I don't want to use my data to do this. So those that are committed to their students and like that, they're actually making plans and doing it. But there are some that they refuse to go do it in their own time, using their own devices, their own data, their own expenses." (HW1).

\section{Theme 4: Exploration and play}

These champions are mindful of the difficulties of changing practice and the importance of iterative innovation, trying new things, allowing room for exploration and experimentation (comment 7). They see the adoption of technologies as fun and playful practices that blur boundaries between their social and professional lives (see comment 8). They innovate in small iterative steps (see also comment 1 ).

Comment 7: "I think people just don't want to sit and puzzle it out because you and I know the more you work with any new technology, the more you discover, the more you learn." (EDU2).

Comment 8: "I enjoy it, I love it. I am intrigued; I want the new iPad to come out now. I want the new iPhone to come out. I explore apps. My kid does it. It's a personality thing, I think because I'm not particularly IT minded. I'm not a coder or a computer freak or... I'll figure and play it out by myself. "(EDU3).

\section{Theme 5: Reflection and resilience}

Many of the champions described their embrace of technology or innovation in their teaching as a result of recognising a problem in their teaching or in terms of student learning practices (see comments 9 and 14). They show curiosity and eagerness to learn both in formal and informal spaces. They continue to adapt their teaching practices to the ever-changing needs of their learners (see comment 10). They are not afraid of criticism and are willing to adjust their practice in response to feedback. Champions often encounter resistance from their colleagues who regard them as a threat to an established status quo, but show resilience in their endeavour to innovate in their practices (see comment 11). Some even seem encouraged by resistance. Having like-minded colleagues seems to be vital, not only for disciplinary and technical, but also moral support (see also comments 1 and 2). Support by management helps, but is not critical (see comment 12).

Comment 9: “...they did so badly in their test. They didn't study the textbook. [My subject] is completely new. Remember, they didn't have it at school but now they have to do it in their first year, it's compulsory. A lot of them have no clue. So I thought and thought and thought, what can I do to design an assessment instrument other than a test for the theory? So I designed this project where they could come in with their own knowledge." (EDU2).

Comment 10: "So I think as reflective practitioners we become more aware of the danger - kind of how fragile the space is that we're working in, but at the same time there's this support and sharing of knowledge. How it's changed my practice I think it's humbled me in that - and also made me more open to listen to the students and to show that we're actually not a hundred percent sure. We're facilitating learning and we're trying our best to be - we need to adapt our practice." (FID).

Comment 11: "I don't think we can keep giving students notes because they will fall back on it. We've got to sort of encourage them to move to this new explorative kind 
of - where they are in control of their education. But a lot of lecturers don't support it and I feel a little bit like we fight against people in our departments. I look at some of the tests that come out and it's a very much regurgitated, here are the notes, these are the questions, this is to regurgitation. So when I teach a course like that I'm fighting like a status-quo in a way."(AS).

Comment 12: 'My advice, if you want to achieve something, go ahead, do it and ask for permission later...' (FID).

\section{Theme 6: Focus on practice}

What is interesting about the findings is that the respondents focus less on tools and the acquisition of skills in their evaluation of attended seminars and training, and more on the affordances of specific tools to support their teaching or student learning practices. One of the tools often mentioned in the interviews is the popular instant messaging application, WhatsApp (see comments 13 and 14). Due to its user-friendliness, accessibility and low data usage, WhatsApp has become a useful tool for many lecturers to engage with their learners beyond the classroom (Gachago, Strydom, Hanekom, Simons, \& Walters, 2015). The comments below show how lecturers are mindful of student needs and contexts and build on students' existing social practices.

Comment 13: “.... like WhatsApp, I've got lots of groups for classes. They were helpful now with these [students] protests where maybe things were changing all the time and you needed to send the information. So you just send the message on WhatsApp group and everyone is aware. So what I usually do is at the beginning of each and every course I'll have the class rep create a WhatsApp group and then put everyone in there...." (ENG1).

Comment 14: “...my Honours students ....are all over the place and they don't come to campus for class. They work, you know they're part time. So we did a lot of their course on WhatsApp. ...they sent me their work for their practical through their phones. ... like their painting. They take a photograph, send it to me, I would look at it. Make it as big as I can and even plug it into my laptop and then I would give advice on their progress. So it saved such a lot of time and it saved them all the travelling. I mean they could work a little bit more, send me another photo." (EDU2).

\section{Theme 7: Change agents}

Champions are aware and mindful of the role and responsibilities they carry as change agents in their institution and associated communities. Their status as champions has given them access to resources and opportunities their colleagues often lack. However, there are responsibilities attached to this status (see comment 15 and 16). They present and share their practice with colleagues, in and outside the institution, through workshops or conference presentations. They often maintain spaces for sharing information on social media, such as Facebook groups (see comment 17). These lecturers often work harder than their colleagues, struggling to keep work/life balances and sometimes run the risk of burning out. Although not prominent, an awareness around social responsibility is implicit and present in their feedback (see comments 14 and 18).

Comment 15: "But the fact is I'm pulling more people in with me, so for example, two of my colleagues now are just doing videos, like they're crazy with their videos. But 
they need to get smarter with the technology they're using ... all you need to do is shift one person. [name of colleague] shifted me; I'm shifting someone else." (ENG3).

Comment 16: "So it is starting to rub off and people are starting to see that it can work and the students love it." (EDU3).

Comment 17: "They [Facebook group members] are stroppy little beasts. They are they really keep me on my toes. It takes me a couple of hours a day ...." (HW1).

Comment 18: "I would say it's a kind of a humbling process because the more you know it kind of makes you think, you know realise your responsibility and that everything you do it's got an impact on the wider student and lecturer community." (FID).

\section{A champion's mindset}

This study set out to explore whether and how the shared characteristics that eLearning champions displayed could be mapped onto existing design thinking models.The seven themes that emerged from interviewing these academics are: collaboration and generosity; learner empathy; problem orientation; exploration and play; reflection and resilience; focus on practice and becoming change agents (see Fig. 2).

When mapping these themes onto the d.mindsets model developed by the Institute of Design at Stanford (d.school, 2011), some can be easily matched (see Table 2). Radical collaboration corresponds to collaboration and generosity, the focus on human values matches learner empathy, craft clarity corresponds to problem orientation, embracing experimentation speaks to exploration and play, while being mindful of process and reflection and resilience, share many commonalities.

However, there are two themes that only partly overlap. While a focus on practice does foreground a bias on doing, academics' views are often framed or supported by educational theories and they express a shared passion for the scholarship of teaching and learning - themes also addressed under 'reflection'. This is not surprising, as many of them have pedagogical degrees or training beyond their disciplinary qualifications and emphasise their interest in pedagogy. Educational theory consequently features in their interviews in that they see 'teaching as a discipline', seemingly

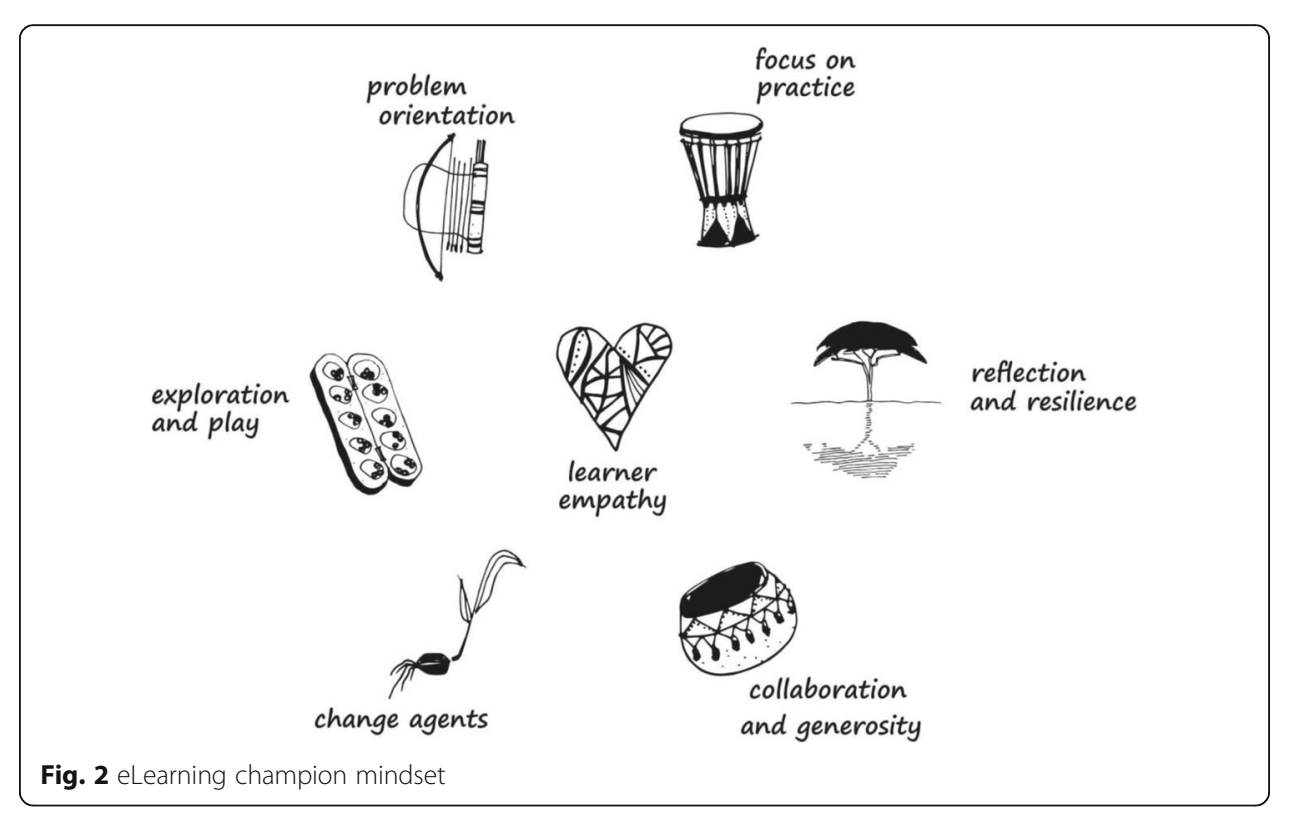


Table 2 Mapping emerging themes onto the d.mindsets model (d.school, 2011)

\begin{tabular}{ll}
\hline d.mindset model & Champion mindset \\
\hline Radical collaboration & Collaboration and generosity \\
Focus on human values and needs/empathy & Learner empathy \\
Craft clarity & Problem orientation \\
Embrace experimentation & Exploration and play \\
Mindful of process & Reflection and resilience \\
Bias towards action & Focus on practice \\
Show don't tell & Change agents \\
\hline
\end{tabular}

contradicting the d.mindset, that argues that design thinkers prioritise practice over theory. As a young institution, the scholarship of teaching and learning has also been identified as one of the prime research areas supported by institutional funding mechanisms.

Also, while the role of change agents displays some of the characteristics of 'show don't tell', i.e. the focus on an ongoing sharing of good practice, the theme of social responsibility goes beyond the mere sharing of practice and starts to craft respondents' identities as responsible change agents. Again this could be explained by the challenges faced by institutions such as ours that serve predominantly under-privileged students, in the current climate of student protests against continuing inequalities in the higher education sector.

\section{Towards design thinking in academic staff development}

Having established that these eLearning champions share a design thinking mindset, what questions remain are whether and how such a mindset could be developed among other colleagues. Is it something that people inherently possess or can it be acquired? And if the latter, how could that be achieved in academic staff development programmes?

Rauth et al. (2010, p. 7) suggest that design thinking education (i.e. the process of teaching design thinking) is able to develop a certain mindset as creative competence that 'culminates in the acquisition of creative confidence, which assures the students of their own ability of acting and thinking creative' (see Fig. 3).

Lawson's (2005) work confirms that this kind of creative problem solving is a skill that can be developed. However, it cannot be learnt by demonstration or observation alone. Mishra and Koehler (2003, p. 20) suggest that it is learned best through the active process of creating and doing'. Koh et al. (2015, p. 40) add that design thinking would be 'best developed through the iterative refinement of artifacts that are being developed to represent design ideas throughout design episodes'. Rather than offering procedural pedagogic approaches, they propose to work with design principles and model design thinking.

In parallel to developing this paper, the team of authors, in collaboration with other colleagues, started designing a staff development course on 'blended learning design' for academics to be offered in 2017. The following section describes strategies we suggest could promote the design thinking mindset emerging from this study in such staff development interventions. 


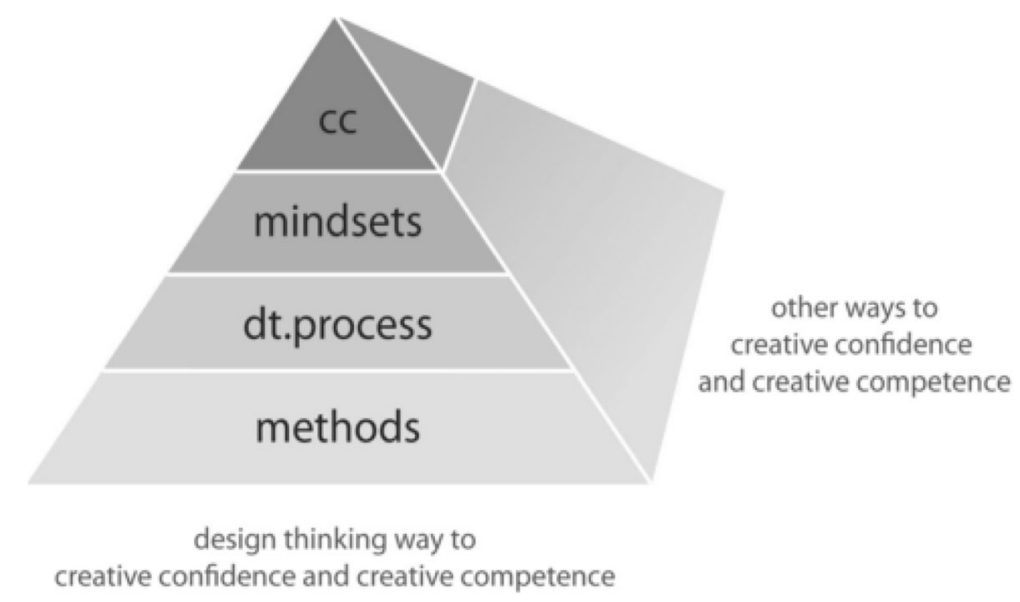

Fig. 3 Rauth et al.'s $(2010$, p. 7$)$ development of creative confidence and competence through design thinking and other disciplines

\section{Collaboration and generosity}

To promote collaboration and generosity among participants, the typical 'silo mentality', so prevalent in higher education, needs to be challenged. Encouraging participants to sign up as course teams with colleagues and, where possible, the formation of interdisciplinary groups in staff development programmes will help in this endeavour. An important part of collaboration is mentoring of participants by more experienced designers. This is vital because working with and from different perspectives allows participants to learn to cope with contexts that are messy, complex and ambiguous (Jobst, Endrejat, \& Meinel, 2011).

\section{Learner empathy}

It is important to emphasise the notion of designing for a specific learner. In higher education, course design is often based on generic definitions of 'a learner'. Instead, focusing on one 'typical' learner, as for example emphasised in the 'persona' activity (Seitzinger, 2016), graphically represented user archetypes can help sharpen and focus the intended design activity around a specific student (De la Harpe, 2014). Ideally, learners should be part of the design process or, if that is not possible, be able to give feedback on design ideas and concepts.

\section{Problem orientation}

Identifying the real need or challenge to design for focuses the process (Pallitt, 2015, Morkel, 2015). Approaches such as the world cafe methodology (Soeder, 2016) can be used to facilitate generative brainstorming in interdisciplinary groups. Koh et al. (2015) caution that academics often jump too quickly at established solutions and design surface level change, without in-depth understanding of the problem. The world cafe method gives participants time to explore the problem from many different viewpoints, thereby remaining in the problem space for longer (Lawson, 2005).

\section{Exploration and play}

Ulibarri et al. (2014) highlight the importance of creating an emotionally supportive, non-judgemental atmosphere to foster creativity. One way to frame learning in a playful way is by using learning metaphors to prompt and guide the learning design. The 
selection of a metaphor may guide the conceptualisation of the learning experience in terms of activities, timing, tools, collaboration, assessment, outcomes, support, and location. Learning experiences could for example be like sitting around a campfire, speed dating or viewing a reality show like "The Amazing Race" (Morkel, 2015).

Rauth et al. (2010, p. 6) argue that a design thinking mindset and creative confidence can be developed through design thinking repetition. Staff development interventions should have various built-in cycles of exploration, re-design and reflection, allowing lecturers to test their interventions repeatedly and collect regular feedback from colleagues and learners. This may help them to move away from the 'striving for perfection' mindset, prevalent in academia and one that stifles innovation, to one that rather looks for feedback on 'work in process' (Ulibarri et al., 2014).

\section{Reflection and resilience}

Strong emphasis should be placed on continuous reflective practice (Hitge \& Morkel, 2013; Hitge, 2016). Participants could be encouraged to write weekly reflections on their design journeys, to obtain regular feedback from peers and students, as well as to facilitate online and face-to-face reflective design conversations with mentors (Lawson, 2005) to foster creativity and innovation. Also, modelling of how to deal with unforeseen circumstances as facilitators can help to promote resilience.

\section{Focus on practice}

When designing a staff development intervention, it is important to consider a holistic exploration of desired learning outcomes: cognitive knowledge transfer of content that learners should acquire, the competencies and skills they need to develop and, most importantly, the mindset that should be fostered. Focusing on all three dimensions minimises the potential danger of what Taheri et al. (2016, p. 9) call a 'creative overconfidence'. This may result from a lack of supporting competences and skills as an outcome of some of the shorter creative thinking trainings currently being offered, and an overemphasis on technologies and tools rather than on practice as can sometimes be seen in hands-on technology training sessions.

\section{Change agents}

How does one encourage more lecturers to use technology creatively in their practice and join the ranks of champions? It may mean drawing from the champions to model and inspire the principles that guided their design thinking and creative confidence. Using their pedagogical innovations as case studies, to be deconstructed and used as examples or 'precedent' (Lawson, 2005; Hitge, 2016), is an important strategy to develop new champions. Jobst and Meinel (2012) call this process of constantly observing others as models in action, 'vicarious experiences'. The success of this approach depends on mentors' ability to externalise their tacit knowledge, i.e. design thinking (Koh et al., 2015) and the mindset that enables it.

\section{Conclusion}

This paper set out to explore and present ways of thinking associated with the innovative practices of academic eLearning champions, in order to develop strategies and principles to inform the design of staff development activities to foster this mindset. 
We first set out to explore shared characteristics emerging from interviews with champions at our institution which were mapped on the d.school's d.mindset (2011), mostly overlapping but also offering interesting nuances emerging from our own institutional context, culture and practices. We then offered some suggestions for strategies or principles for the design of staff development initiatives that could promote such a mindset. Through the fostering of a design thinking mindset, we hope to facilitate the development of creative confidence in academics and consequently increase innovation in teaching and learning. The impact of this staff development programme on the cultivation of creative competence and confidence will be part of further research.

\section{Acknowledgements}

We would like to thank the eLearning champions who offered us their time and insights into their design practices. We would also like to acknowledge the feedback we received when presenting a previous version of this paper at the 2016 ICED/HELTASA conference in Cape Town and the thoughtful comments from the reviewers of this journal that helped to improve the paper. Finally we need to thank the institution, which supported this study through RIFTAL funding. The authors declare that they have no competing interests.

\section{Authors' contributions}

All authors read and approved the final manuscript.

\section{Publisher's note}

Springer Nature remains neutral with regard to jurisdictional claims in published maps and institutional affiliations.

Received: 21 December 2016 Accepted: 26 June 2017

Published online: 19 July 2017

\section{References}

Adams Becker, S., Cummins, M., Davis, A., Freeman, A., Hall Giesinger, C. Ananthanarayanan, V. (2017). NMC Horizon Report. 2017 Higher Education Edition. Retrieved from https://www.nmc.org/publication/nmc-horizon-report-2017higher-education-edition/

Baeck A., \& Gremett P. (2012). Design thinking. In H. Degen, \& X. Yuan (Eds.), UX best practices: How to achieve more impact with user experience (pp. 229-233). New York: McGraw-Hill.

Beath, C. M. (1991). Supporting the information technology champion. MIS Quarterly, 15, 355-372. 10.2307/249647. Retrieved from http://www.jstor.org/stable/249647

Bozalek V. G., Ng'ambi D., \& Gachago D. (2013). Transforming teaching with emerging technologies: Implications for higher education institutions. South African Journal of Higher Education, 27(2), 419-436.

Braun V., \& Clarke V. (2006). Using thematic analysis in psychology. Qualitative Research in Psychology, 3(2), 77-101.

Brown C., \& Czerniewicz L. (2010). Debunking the 'digital native': Beyond digital apartheid, towards digital democracy. Journal of Computer Assisted Learning, 26(5), 357-369.

Cloete N., \& Gillwald A. (2014). South Africa: Informational development and human development-rights vs capabilities In M. Castells, \& P. Himanen (Eds.), Reconceptualizing development in the global information age (pp. 140-174). New York: Oxford University Press.

Cross N. (2007). Designerly ways of knowing (). Basel: Birkhaeuser.

Cross N. (2011). Design thinking (). New York: Berg.

d.school (2011). Design Mindset and Process (PowerPoint). Retrieved from https://dschool.stanford.edu/resources/ getting-started-with-design-thinking

Di Russo, S. (2016). Understanding the behaviour of design thinking in complex environments, Unpublished PhD thesis. Melbourne: Swinburne University.

Gachago D., Strydom S., Hanekom P., Simons S., \& Walters S. (2015). Crossing boundaries: Lecturers' perspectives on the use of WhatsApp to support teaching and learning in higher education. Progressio, 37(1), 172-187.

Hitge, L. (2016). Cognitive apprenticeship in architecture education: Using a scaffolding tool to support conceptual design, Unpublished Master Thesis. Cape Town: University of Cape Town.

Hitge, L., \& Morkel, J. (2013). Using cognician for reflection and articulation. Paper presented at the CPUT Teaching with Technology Day. Retrieved from https://www.youtube.com/watch?v=nGw-Nmwy9QU

Ivala E. (2016). Educational technology training: Staff development approaches. International Journal of Educational Sciences, 14(3), 195-204.

Jobst B., Endrejat P., \& Meinel C. (2011). Does design thinking mediate critical innovation skills? An interview approach to synthesize five competencies taught at the D. School. In International conference on Engineering and product design education (pp. 199-204). London: City University.

Jobst B., \& Meinel C. (2012). How can creative self-efficacy be fostered in design education ? In International conference on Engineering and product design education (pp. 5220-5226). Antwerp: Artesis University College.

Koh J. H. L., Chai C. S., Wong B., \& Hong H. Y. (2015). Design thinking for education: Conceptions and applications in teaching and learning (). Singapore: Springer.

Laurillard D. (2012). Teaching as a design science: Building pedagogical patterns for learning and technology (). New York: Routledge.

Lawson, B. (2005). How designers think: The design process demystified (4th ed., ). Oxford: Architectural Press. 
Luka I. (2014). Design thinking in pedagogy origin of design thinking. Journal of Education Culture and Society, 2, 63-74.

MacQuaid, H. (2015). The da Vinci re-Code: Mapping da Vincian principles to design-thinking attributes. Retrieved from http://futuretonic.co.uk/7-elements-2-650x650/.

Michlewski K. (2008). Uncovering design attitude: Inside the culture of designers. Organization Studies, 29(3), $373-392$.

Mishra, P., \& Koehler, M. (2003). Not "what" but "how": Becoming design-wise about educational technology. In Y. Zhao (Ed.), What do teachers need to know (pp. 1-28). Educational Technology Publications.

Morkel, J. (2015). Ideate crea8 iterate: A learning design workshop, ELearning Update, Caesar's Palace, Johannesburg. Retrieved from https://www.slideshare.net/jolandamorkel/learning-design-workshop-at-elearnigupdate-2015

Morkel, J., \& Pallitt, N. (2015). Learning design workshop series. E/merge Africa online. Retrieved from https://www. youtube.com/playlist?list=PLgNzHqwrWe5zbm13bBIMDekDTd3V7wfk3

Ng'ambi D., Brown C., Bozalek V., Gachago D., \& Wood D. (2016). Technology enhanced teaching and learning in South African higher education - a rearview of a 20 year journey. British Journal of Educational Technology, 47(5), 843-858.

Porcini M. (2009). Your new design process is not enough! Hire design thinkers! Design Management Institute (DMI) Review, 20(3), 6-18.

Rauth I., Köppen E., Jobst B., \& Meinel C. (2010). Design thinking: An educational model towards creative confidence. In 1st International conference on design creativity (ICDC 2010) (pp. 1-8).

Razzouk R., \& Shute V. (2012). What is design thinking and why is it important? Review of Educational Research, 82(3), $330-348$.

Rogers E. M. (2010). Diffusion of innovations (). New York: Simon and Schuster.

Seitzinger, J. (2016). 10 Learner experience powers from experience girl! iMOOT16 Conference, 26-27 May. Retrieved from https://www.slideshare.net/catspyjamas/10-learner-experience-powers-from-experience-girl-imoot16-agents-of-change

Smulders, F. E. H. M., Dorst, K., \& Vermaas, P. E. (2014). Applying design thinking elsewhere: Organizational context matters. Proceedings of the 19th DMI: Academic design management conference, (pp. 2797-2817). Boston: Design Management Institute.

Soeder, U. (2016). The World Cafe Design Principles. Retrieved from http://www.theworldcafe.com/keyconceptsresources/design-principles/

Taheri M., Unterholzer T., Strasse H., Hölzle K., \& Meinel C. (2016). An educational perspective on design thinking learning outcomes. In The ISPIM innovation forum (). Boston: ISPIM.

Ulibarri N., Cravens A. E., Cornelius M., Royalty A., \& Nabergoj A. S. (2014). Research as design: Developing creative confidence in doctoral students through design thinking. International Journal of Doctoral Studies, 9, 249-270.

Uys P. (2007). Enterprise-wide technological transformation in higher education: The LASO model. International Journal of Educational Management, 21(3), 238-253.

Uys P. M., Nleya P., \& Molelu G. B. (2004). Technological innovation and management strategies for higher education in Africa: Harmonizing reality and idealism. Educational Media International, 41(1), 67-80.

Vaismoradi M., Turunen H., \& Bondas T. (2013). Content analysis and thematic analysis: Implications for conducting a qualitative descriptive study. Nursing \& Health Sciences, 15(3), 398-405.

Van Zyl, I., \& De la Harpe, R. (2014). Mobile Application Design for Health Intermediaries. Considerations for Information Access and Use. Proceedings of the International Conference on Health Informatics (HEALTHINF), (pp. 323-328), Angers

Van Zyl, I., \& Sabiescu, A. 2016. Symbolic narratives and the role of meaning: Encountering technology in South African primary education. The African Journal of Information and Communication (AJIC), 18, 95-115.

\section{Submit your manuscript to a SpringerOpen ${ }^{\oplus}$ journal and benefit from:}

- Convenient online submission

- Rigorous peer review

- Open access: articles freely available online

- High visibility within the field

- Retaining the copyright to your article

Submit your next manuscript at $\gg$ springeropen.com 